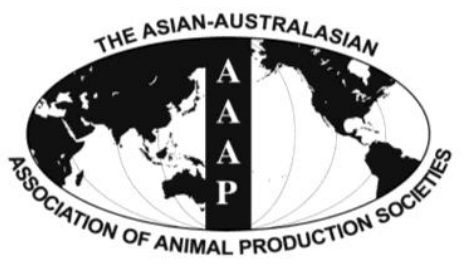

Asian-Aust. J. Anim. Sci.

Vol. 25, No. $10: 1389$ - 1394

October 2012

www.ajas.info

http://dx.doi.org/10.5713/ajas.2012.12229

\title{
Phenolic Composition, Fermentation Profile, Protozoa Population and Methane Production from Sheanut (Butryospermum Parkii) Byproducts In vitro
}

\author{
Raghavendra Bhatta*, Saravanan Mani, Luna Baruah and K. T. Sampath \\ Energy Metabolism Laboratory, National Institute of Animal Nutrition and Physiology, Bangalore 560 030, India
}

\begin{abstract}
Sheanut cake (SNC), expeller (SNE) and solvent extractions (SNSE) samples were evaluated to determine their suitability in animal feeding. The CP content was highest in SNSE (16.2\%) followed by SNE (14.7\%) and SNC (11.6\%). However, metabolizable energy (ME, MJ/kg) was maximum in SNC (8.2) followed by SNE (7.9) and SNSE (7.0). The tannin phenol content was about 7.0 per cent and mostly in the form of hydrolyzable tannin (HT), whereas condensed tannin (CT) was less than one per cent. The in vitro gas production profiles indicated similar y max (maximum potential of gas production) among the 3 by-products. However, the rate of degradation (k) was maximum in SNC followed by SNE and SNSE. The $\mathrm{t}^{1 / 2}$ (time taken for reaching half asymptote) was lowest in SNC (14.4 h) followed by SNE (18.7 h) and SNSE (21.9 h). The increment in the in vitro gas volume (ml/200 mg DM) with PEG (polyethylene glycol)-6000 (as a tannin binder) addition was 12.0 in SNC, 9.6 in SNE and 11.0 in SNSE, respectively. The highest ratio of $\mathrm{CH}_{4}(\mathrm{ml})$ reduction per $\mathrm{ml}$ of the total gas, an indicator of the potential of tannin, was recorded in SNE (0.482) followed by SNC $(0.301)$ and SNSE (0.261). There was significant $(\mathrm{p}<0.05)$ reduction in entodinia population and total protozoa population. Differential protozoa counts revealed that Entodinia populations increased to a greater extent than Holotricha when PEG was added. This is the first report on the antimethanogenic property of sheanut byproducts. It could be concluded that all the three forms of SN byproducts are medium source of protein and energy for ruminants. There is a great potential for SN by-products to be incorporated in ruminant feeding not only as a source of energy and protein, but also to protect the protein from rumen degradation and suppress enteric methanogenesis. (Key Words: Sheanut Meal, In vitro, Tannin, Phenolics, Methane, Protozoa)
\end{abstract}

\section{INTRODUCTION}

At the global level, the reasons to push for recycling of organic by-products and wastes in animal feeding fall into two different and complementary trends: in highlydeveloped industrialized regions of the world use of such products as unusual feedstuffs ensures more economical and ecological disposal, while in the developing countries like India this is a way to augment both quantity and quality of feed supply. There is acute shortage of conventional feeding ingredients with a consequent dwindling in productivity and profitability. As the production and processing of food becomes more and more industrialized, the sources of supply are increasingly located near large urban centres, i.e. near the demand. This in turn logistically enhances the conditions for industrializing the processing of

\footnotetext{
* Corresponding Author: Raghavendra Bhatta. Fax: +91-8025711420, E-mail: ragha0209@yahoo.com

Submitted Apr. 26, 2012; Accepted Jun. 25, 2012; Revised Jul. 2, 2012
}

by-products as livestock feed. Since the beginning of the 20th century the utilization of by-products as feed was accompanied by efforts in feed legislation to avoid negative effects on animals' health and the quality of food. On the one hand the utilization is intended due to ecological and economical reasons, on the other hand the use of byproducts will be impaired more and more due to reduced social acceptance, i.e. the willingness of people to accept food from animals that were fed some groups of byproducts (for example meat and bone meal). Therefore, incorporation of byproducts in animal feeding can help food processors earn revenue while preventing pollution.

The green fruit of Shea (Butryospermum parkii) tree has a pulp that covers the seed or nut. The harvest follows 3 to 5 years cycle and yields $80 \mathrm{~kg}$ of nuts and from these nuts, oil will be extracted and leaving the residue (Abidemi et al., 2009; Kumar et al., 2010). Sheanut meal is now receiving increased attention as a potential feed ingredient due to the increased amounts that are available as a result of high demand for shea fat for cosmetics and as a cocoa butter 
substitute in chocolate (Lipp and Anklam, 1998). The phenolic components and the antimethanogenic potential of sheanut products have not yet been fully explored. The present in vitro study was therefore undertaken to evaluate the sheanut cake, expeller and solvent extractions for their suitability as animal feed.

\section{MATERIALS AND METHODS}

\section{Experimental samples}

The sheanut cake, expeller (obtained after oil extraction by mechanical pressing) and solvent extractions (obtained after oil extraction using an organic solvent such as hexane) were obtained from the local market. The samples were ground to pass through $1 \mathrm{~mm}$ sieve and used for further analysis. The dried and milled samples were analyzed for their chemical composition. The protein contents were analyzed using standard method (AOAC, 1995). Neutral detergent fibre (NDF), acid detergent fibre (ADF) and acid detergent lignin (ADL) were analyzed according to Van Soest et al. (1991). The samples were analyzed without $\alpha$ amylase and sodium sulfite. Detergent fibre values were expressed including residual ash.

\section{Tannin assays}

For tannin assays, samples were ground to fine powder in a Cycoltec mill (Foss, Denmark) and $0.2 \mathrm{~g}$ of samples were extracted in $10 \mathrm{ml}$ aqueous acetone (acetone: water, 7:3) twice for $20 \mathrm{~min}$ in an ultrasonic water bath. The extracted samples were centrifuged $\left(6,000 \times g, 10 \mathrm{~min}, 4^{\circ} \mathrm{C}\right)$, and the supernatants were combined and used for tannin analysis on the same day.

Tannin assays were according to Makkar (2003). Total phenols and total tannins in the extract were determined by a modification of the Folin-Ciocalteu method (Makkar, 2003) using polyvinylpolypyrrolidone (PVPP) to separate tannin phenols from non-tannin phenols, and condensed tannins (CT) were determined by the butanol-HCl-iron method. Both total phenols and total tannins were expressed as tannic acid equivalent and condensed tannins as leucocyanidin equivalent. The hydrolysable tannin was calculated as the difference between total tannin and CT.

\section{In vitro gas production test}

For the in vitro gas production test, rumen liquor was collected $1.5 \mathrm{~h}$ after morning feeding from two cannulated Holstein Friesian crossbred bulls fed with a total mixed ration based on finger millet (Elusine coracana) straw (ad libitum) and commercial concentrate mixture (about $3.0 \mathrm{~kg}$ ). The rumen liquor, strained through 3 layers of muslin cloth, was pooled and used as the source of inoculum. A total of $200 \mathrm{mg}$ air equilibrated samples were incubated with $30 \mathrm{ml}$ buffered rumen inoculum $(10 \mathrm{ml}$ rumen fluid $+20 \mathrm{ml}$ buffer) (Menke et al., 1979) in $100 \mathrm{ml}$ calibrated syringes and placed in a water bath maintained at $39^{\circ} \mathrm{C}$. The incubations were conducted in triplicate for each sample on 2 successive days and these incubations were repeated three times, with an interval of $1 \mathrm{wk}$. Incubations without sample served as the blanks with every set. The difference in the composition and activity of the rumen inoculum among incubations was controlled by parallel incubation of reference standard feedstuffs as suggested by Menke et al. (1979). Incubations were run for $24 \mathrm{~h}$ with recording of gas production after 6 and $24 \mathrm{~h}$. The interference of tannins on in vitro fermentation was assessed using PEG-6000 as a tannin binder. The magnitude of the increase in gas volume on PEG addition to the substrate at a ratio of 2:1 was taken as an index of tannin's interference on rumen fermentation. To determine the rate of degradation $\left(\mathrm{t}^{1 / 2}\right)$ of the substrate, the samples were incubated for $96 \mathrm{~h}$, with recording of the gas volumes after 2, 4, 6, 8, 10, 12, 24, 36, 48, 72 and $96 \mathrm{~h}$. The data was subjected to graph-pad prism programme to determine $\mathrm{Y}$ min (minimum amount of gas production), $\mathrm{Y}$ $\max$ (maximum potential of gas production), $\mathrm{t}^{1 / 2}$ and $\mathrm{k}$ (rate of gas production).

The metabolizable energy (ME) was calculated using the equation suggested by Krishnamoorthy et al. (1995).

\section{Gas and methane estimation}

After $24 \mathrm{~h}$ of incubation, total gas was recorded from visual assessment of the calibrated scale on the syringe. The gas produced due to fermentation of the substrate was calculated by subtracting gas produced in blank syringe (containing no substrate, but only the inoculum and buffer) from total gas produced in the syringe containing substrate and inoculums. The gas produced in standard syringe (containing concentrate and hay standard from Hohenheim University) was used to check variation in the quality of inoculum. For methane estimation $1 \mathrm{ml}$ gas was sampled from the head space of syringe in an airtight syringe (Hamilton) and injected into Thermo-Fisher gas chromatograph equipped with thermal conductivity detector and stainless steel column packed with Porapak-Q. Temperature of injector oven, column oven and detector were 60,100 and $110^{\circ} \mathrm{C}$, respectively. Based on the methane percentage estimated in the gas sample, methane production was calculated (methane volume $(\mathrm{ml})=$ methane $\% \times$ total gas produced $(\mathrm{ml})$ in $24 \mathrm{~h}$ ).

\section{Rumen fluid analysis}

After the termination of the incubation $(24 \mathrm{~h})$ the supernatant was kept under $-20^{\circ} \mathrm{C}$ until further analysis. The rumen fluid samples were analyzed for ammonia $\mathrm{N}$ (Conway, 1957) and total volatile fatty acid (Barnett and Reid, 1957). 


\section{Enumeration of protozoa}

Rumen ciliates were identified according to Hungate (1966). Spirotrichs not identified to generic level were classified into small Spirotrichs (mainly Entodinia with an average size $42 \mu \mathrm{m} \times 23 \mu \mathrm{m}$ ) and large Spirotrichs (mainly Diplodinia with an average size of $132 \mu \mathrm{m} \times 66 \mu \mathrm{m})$. The protozoa numbers were calculated according to Kamra et al. (1991).

\section{Statistical analysis}

Data on all the parameters such as methane per cent, per cent increase in methane, protozoa count were analyzed using ANOVA model using SAS 9.0/SPSS and standard error of mean and LSD were computed. The model $Y i j=$ $\mu+\alpha i+\beta j+\varepsilon i j$, where $Y i j$ is the dependent variable, $\mu$ is the least squares mean, $\alpha i$ is the effect of PEG and $\beta j$ is the effect of sheanut byproducts was used for evaluating the effect of PEG.

\section{RESULTS AND DISCUSSION}

Phenolic components and antimethanogenic potential of sheanut byproducts have not yet been explored. The nutrient composition and phenolic fractions of sheanut cake (SNC), expeller (SNE) and solvent extractions (SNSE) are presented in Table 1. The CP $(\%)$ was highest in SNSE (16.2) followed by SNE (14.7) and SNC (11.6). Metabolizable energy (ME, MJ/kg) was maximum in SNC (8.2) followed by SNE (7.9) and SNSE (7.0). However, Okai et al. (1995) recorded $19.0 \mathrm{MJ} / \mathrm{kg}, \mathrm{ME}$ in $\mathrm{SNC}$, probably due to the difference in the nutrient composition. The protein and energy contents of SN byproducts indicated that they are medium source of protein and energy for ruminants. The nutrient composition is almost similar to palm kernel meal (INRA, 2004). The tannin phenol content was about 7.0 per cent and most of them were in the form of hydrolyzable tannin (HT). The condensed tannin (CT) was less than 1.0 per cent in SN byproducts. The concentrations of tannins in sheanut products were high relative to other feedstuffs such as sorghum and peas (Dei et al., 2007).

The gas production profiles presented in Table 2 indicated similar y max (maximum potential of gas production) among the samples. However, the maximum rate of degradation $(\mathrm{k})$ was highest in SNC followed by SNE and SNSE. The $\mathrm{t}^{1 / 2}$ (time taken for reaching half
Table 1. Nutrient composition and phenolic fractions (\% DM) of sheanut cake, expeller and solvent extraction

\begin{tabular}{lccc}
\hline & SN-cake & SN- expeller & $\begin{array}{c}\text { SN-solvent } \\
\text { extracted }\end{array}$ \\
\hline Organic matter & 84.9 & 84.9 & 85.0 \\
Crude protein & 11.6 & 14.7 & 16.2 \\
NDF & 52.9 & 55.2 & 61.9 \\
ADF & 35.5 & 35.9 & 41.9 \\
ADL & 6.70 & 7.10 & 4.80 \\
Ether extract & 4.90 & 2.80 & 1.60 \\
Total ash & 5.10 & 5.10 & 5.00 \\
ME (MJ/kg DM) & 8.2 & 7.9 & 7.0 \\
Total phenols & 7.73 & 6.98 & 7.06 \\
Total tannin phenols & 7.37 & 6.77 & 6.81 \\
$\quad$ Condensed tannin & 0.66 & 0.49 & 0.40 \\
Hydrolysable tannin & 6.71 & 6.28 & 6.41 \\
\hline
\end{tabular}

SN-cake $=$ Sheanut cake; SN-expeller $=$ Sheanut expeller; $\mathrm{SN}$-solvent extracted $=$ Sheanut solvent extracted .

$\mathrm{NDF}=$ Neutral detergent fibre, $\mathrm{ADF}=\mathrm{Acid}$ detergent fibre $\mathrm{ADL}=\mathrm{Acid}$ detergent lignin.

asymptote) was lowest in SNC (14.4 h) followed by SNE $(18.7 \mathrm{~h})$ and SNSE $(21.9 \mathrm{~h})$, therefore SNC is a better source of energy for ruminants as compared to SNE or SNSE.

The gas production with PEG is presented in Table 3. The increment in in vitro gas volume $(\mathrm{ml} / 200 \mathrm{mg} \mathrm{DM})$ with PEG over and above that of without PEG was 12.0 in SNC, 9.6 in SNE and 11.0 in SNSE, respectively. Tannin bioassay (\% increase in gas volume with PEG-6000), a measure of the biological activity of tannin was highest in SNC. In an earlier study Bhatta et al. (2001) recorded similar findings with tamarind (Tamarindus indica) seed husk (containing $140 \mathrm{~g} \mathrm{CT} \mathrm{kg}^{-1} \mathrm{DM}$ ) when incubated with PEG. The highest ratio of $\mathrm{CH}_{4}(\mathrm{ml})$ reduction per $\mathrm{ml}$ of the total gas due to the presence of active tannin was recorded in SNE (0.482) followed by SNC (0.301) and SNSE (0.261). This ratio could be used as a effective tool to screen and categorize large number of samples to determine their capacity to suppress methanogenesis in vitro because it takes into account the total gas production (rumen fermentation) also. Higher ratios of $\mathrm{CH}_{4}$ reduction per $\mathrm{ml}$ of the total gas indicate that a particular candidate would be better as a rumen modifier for methane reduction than compounds yielding lower ratios. Reduced rumen methanogenesis could be linked to the role of sheanut tannins in reducing

Table 2. Fermentation kinetics of sheanut cake, expeller and solvent extractions

\begin{tabular}{|c|c|c|c|c|c|}
\hline & SN-cake & $\mathrm{SN}$ - expeller & SN-solvent extracted & SEM & $\mathrm{p}$ \\
\hline $\mathrm{Y} \min (\mathrm{ml})$ & $0.008^{\mathrm{a}}$ & $0.122^{b}$ & $2.268^{c}$ & 0.002 & 0.0236 \\
\hline $\mathrm{Y} \max (\mathrm{ml})$ & $15.13^{b}$ & $15.41^{\mathrm{c}}$ & $14.82^{\mathrm{a}}$ & 0.569 & 0.0451 \\
\hline K (Rate of degradation) & $0.04802^{c}$ & $0.03702^{b}$ & $0.03154^{\mathrm{a}}$ & 0.002 & 0.0365 \\
\hline$\left(\mathrm{t}^{1 / 2}\right)$ Half-time $(\mathrm{h})$ & $14.43^{\mathrm{a}}$ & $18.72^{b}$ & $21.98^{c}$ & 1.030 & 0.0249 \\
\hline
\end{tabular}

Means in a row with different superscript differ significantly $(\mathrm{p}<0.05)$. 
Table 3. Fermentation kinetics of sheanut cake, expeller and solvent extractions with PEG-6000 in vitro

\begin{tabular}{|c|c|c|c|c|c|}
\hline $\begin{array}{l}\text { Gas production } \\
(\mathrm{ml} / 200 \mathrm{mg} \mathrm{DM})\end{array}$ & SN-cake & SN- expeller & SN-solvent extracted & SEM & $\mathrm{p}$ \\
\hline $8 \mathrm{~h}$ & $42.0^{\mathrm{a}}$ & $44.3^{b}$ & $45.6^{c}$ & 0.56 & 0.0356 \\
\hline With PEG & $52.0^{\mathrm{a}}$ & $49.0^{\mathrm{b}}$ & $53.0^{\mathrm{c}}$ & 1.06 & 0.0426 \\
\hline $24 \mathrm{~h}$ & $53.0^{\mathrm{a}}$ & $57.0^{\mathrm{b}}$ & $59.0^{\mathrm{c}}$ & 1.25 & 0.0365 \\
\hline With PEG & $65.0^{\mathrm{a}}$ & $67.6^{\mathrm{b}}$ & $69.6^{c}$ & 1.05 & 0.0435 \\
\hline Total gas & $23.0^{\mathrm{a}}$ & $27.0^{\mathrm{b}}$ & $28.3^{c}$ & 1.26 & 0.0365 \\
\hline With PEG & $35.0^{\mathrm{a}}$ & $37.6^{\mathrm{b}}$ & $39.3^{c}$ & 0.98 & 0.0345 \\
\hline Net gas & $6.00^{\mathrm{a}}$ & $10.0^{\mathrm{b}}$ & $11.3^{\mathrm{c}}$ & 1.96 & 0.0375 \\
\hline With PEG & $18.0^{\mathrm{a}}$ & $19.6^{\mathrm{b}}$ & $22.3^{c}$ & 0.96 & 0.0356 \\
\hline $\begin{array}{l}\text { Tannin bioassay } \\
\text { (\% increase in gas production) }\end{array}$ & $200.0^{\mathrm{b}}$ & $96.0^{\mathrm{a}}$ & $97.4^{\mathrm{a}}$ & 3.26 & 0.0423 \\
\hline Methane (ml/200 mg DM) & $1.89^{\mathrm{a}}$ & $2.86^{\mathrm{b}}$ & $3.04^{\mathrm{c}}$ & 0.256 & 0.0365 \\
\hline With PEG & $5.59^{\mathrm{a}}$ & $7.42^{b}$ & $5.37^{\mathrm{a}}$ & 0.958 & 0.0240 \\
\hline Methane reduction $/ \mathrm{ml}$ of total gas reduction & $0.301^{\mathrm{b}}$ & $0.482^{\mathrm{c}}$ & $0.261^{\mathrm{a}}$ & 0.001 & 0.0461 \\
\hline
\end{tabular}

SN-cake = Sheanut cake; SN-expeller $=$ Sheanut expeller; SN-solvent extracted = Sheanut solvent extracted; PEG = Polyethylene glycol. Means in a row with different superscript differ significantly $(\mathrm{p}<0.05)$.

protozoa and/or methanogenic archea population (Bhatta et al., 2009). Phenolic acids such as $p$-coumaric acids, ferulic acids, cinnamic acids and phloretic acids and some monomeric phenolics were reported to decrease rumen $\mathrm{CH}_{4}$ (Field and Lettinga, 1987; Asiegbu et al., 1995).

The total and differential protozoa counts with and without PEG are presented in Table 4 . There was significant $(\mathrm{p}<0.05)$ reduction in the entodinia population and in turn total protozoa population in samples without PEG as compared to that of samples with added PEG. Differential protozoa counts revealed that Entodinia populations increased to a greater extent than Holotricha with added PEG thus confirming higher susceptibility of Entodinia to phenolics present in sheanut byproducts. Wang et al. (2009) reported that protozoa help methanogens reduce $\mathrm{CO}_{2}$ to $\mathrm{CH}_{4}$. Hence, anti-protozoal effect of tannins could decrease $\mathrm{CH}_{4}$ production ridding methanogen populations attached to protozoa. Therefore, $\mathrm{CH}_{4}$ production could be higher when protozoa are present in greater numbers in the rumen than when absent or present in low number (Jouany and Lassalas, 1997). There are conflicting reports on the effects of HT and CT on ruminal ciliated protozoa counts such as HT were reported to have no effect on protozoa counts (Sliwinski et al., 2002), whereas, Leinmuller (1991) reported that CT was more inhibitory than HT on protozoa. Terrill et al. (1992) did not observe any adverse effect of CT-containing Sulla (Hadysarum coronarium) on protozoa numbers. Hess et al. (2001) suggested that only a small portion of total $\mathrm{CH}_{4}$ production was due to the presence of methanogens attached with the ciliate protozoa. Dohme et al. (1999) also reported inhibition of in vitro $\mathrm{CH}_{4}$ emission both in defaunated and faunated rumen liquor with coconut oil. Machmüller (2003) reported an increased number of methanogens in defaunated sheep and suggested that

Table 4. Total and differential protozoa population (per ml) with and without PEG from sheanut cake, expeller and solvent extractions with PEG-6000 in vitro

\begin{tabular}{clcccc}
\hline & SN-cake & SN- expeller & SN-solvent extracted & SEM & p \\
\hline Entodinia $\left(10^{5}\right)$ & & & & & \\
Small & $0.172^{\mathrm{b}}$ & $0.162^{\mathrm{a}}$ & $0.158^{\mathrm{a}}$ & 0.028 & 0.0502 \\
$\quad$ With PEG & $0.183^{\mathrm{a}}$ & $0.185^{\mathrm{b}}$ & $0.170^{\mathrm{a}}$ & 0.021 & 0.0464 \\
Large & 0.060 & 0.054 & 0.057 & 0.001 & 0.0658 \\
With PEG & 0.074 & 0.071 & 0.061 & 0.001 & 0.0560 \\
Holotricha $\left(10^{5}\right)$ & & & & 0.001 & 0.0654 \\
Isotricha & 0.009 & 0.007 & 0.009 & 0.001 & 0.1256 \\
With PEG & 0.005 & 0.006 & 0.012 & 0.001 & 0.1547 \\
Dasytricha & 0.003 & 0.002 & 0.005 & 0.001 & 0.1635 \\
With PEG & 0.003 & 0.004 & 0.006 & 0.025 & 0.0496 \\
Total $\left(10^{5}\right)$ & 0.243 & 0.226 & $0.248^{\mathrm{a}}$ & 0.035 & 0.0469 \\
With PEG & $0.264^{\mathrm{b}}$ & $0.265^{\mathrm{b}}$ & & & \\
\hline
\end{tabular}

SN-cake = Sheanut cake; SN-expeller = Sheanut expeller; SN-solvent extracted = Sheanut solvent extracted; PEG = polyethylene glycol. 
Table 5. Ammonia-N and TVFA from sheanut cake, expeller and solvent extractions with PEG-6000 in vitro

\begin{tabular}{lccccc}
\hline & SN-cake & SN- expeller & SN-solvent extracted & SEM & p \\
\hline $\mathrm{NH}_{3}-\mathrm{N}(\mathrm{m} \mathrm{mol} / \mathrm{dl})$ & $13.6^{\mathrm{c}}$ & $12.8^{\mathrm{b}}$ & $11.5^{\mathrm{a}}$ & 0.965 & 0.0325 \\
With PEG & $16.4^{\mathrm{c}}$ & $14.7^{\mathrm{b}}$ & $13.1^{\mathrm{a}}$ & 0.026 & 0.0436 \\
$\mathrm{TVFA}(\mathrm{mg} / \mathrm{dl})$ & $15.6^{\mathrm{b}}$ & $11.3^{\mathrm{a}}$ & $11.6^{\mathrm{a}}$ & 1.236 & 0.0365 \\
With PEG & $15.1^{\mathrm{b}}$ & $12.1^{\mathrm{a}}$ & $15.2^{\mathrm{b}}$ & 0.965 & 0.0523 \\
\hline
\end{tabular}

$\mathrm{SN}$-cake $=$ Sheanut cake; $\mathrm{SN}$-expeller $=$ Sheanut expeller; $\mathrm{SN}$-solvent extracted $=$ Sheanut solvent extracted; $\mathrm{PEG}=$ Polyethylene glycol; $\mathrm{NH}_{3}-\mathrm{N}=$ Ammonia-N; TVFA = Total volatile fatty acids.

Means in a row with different superscript differ significantly $(\mathrm{p}<0.05)$.

association between protozoa and methanogens does not play an important role in rumen methanogenesis.

The ammonia $\mathrm{N}$ and TVFA concentrations with and without PEG are presented in Table 5. Reduced TVFA concentration $(p<0.05)$ in SNSE indicated adverse effect on the in vitro fermentation. Effect of tannin on volatile fatty acid production varied. Tannic acids have been reported to reduce VFA production (Vogels et al., 1980; Hristov et al., 2003). Inhibition of fibre degradation also shift fatty acid composition away from acetate and hence less production of hydrogen and less $\mathrm{CH}_{4}$ fermentation (Jayanegara et al., 2012). Methane reduction could be due to direct effect (reduction in archea) or indirect effect (reduction in protozoa) (Bhatta et al., 2009) or due to reduced digestibility of nutrients. Since there was reduction in the protozoa and but no significant reduction in the TVFA (except SNSE), we assume that methane suppression recorded in SNC and SNE was due to direct/indirect effect of tannin.

There was significant reduction $(\mathrm{p}<0.05)$ in the $\mathrm{NH}_{3}-\mathrm{N}$ concentration in the absence of PEG confirming the protein binding properties of tannin present in sheanut byproducts (Bhatta et al., 2002; 2005). Since tannins are recognized as protein binders, there was reduced in vitro $\mathrm{NH}_{3}-\mathrm{N}$ concentration $(\mathrm{p}<0.05)$ in all the samples. According to Leinmuller and Menke (1990) HT and protein usually form complexes at an optimal $\mathrm{pH}$ range of 3 to 4 , but complexes also occur under typical rumen $\mathrm{pH}$ of 6 to 7 . Some ruminal bacteria dissociate the protein-HT complexes. However, dissociation of protein-CT complexes is difficult (McSweeny et al., 2001). The observed difference in the $\mathrm{NH}_{3}-\mathrm{N}$ concentration among samples was attributable to the reversible nature of protein-HT complex. In the absence of tannin, degradability of protein was higher, resulting in greater $\mathrm{NH}_{3}-\mathrm{N}$ concentration, possibly because of inhibition of microbial deaminase by tannins (Leinmuller and Menke, 1990). Lower $(\mathrm{p}<0.05) \quad \mathrm{NH}_{3}-\mathrm{N}$ concentration may be attributed to the inhibition of the bacteria-degrading activity of tannins (Jouany, 1994). Lower $\mathrm{NH}_{3}-\mathrm{N}$ in our samples was a result of protein binding property of tannins. This is another reason for incorporating $\mathrm{SN}$ byproducts in ruminant diets to protect highly degradable protein. However, long term animal feeding studies need to be carried out to determine the palatability of these byproducts and performance of animals.

\section{CONCLUSIONS}

The protein and energy contents of SN extractions established that all the three forms are medium source of protein and energy for ruminants. There is a great potential for SN byproducts to be incorporated in ruminant feeding not only as a source of energy and protein, but also to suppress enteric methanogenesis.

\section{ACKNOWLEDGEMENT}

The financial help provided to this work by the Department of Biotechnology, Ministry of Science \& Technology, Government of India vide project no. BT/PR9018/AAQ/01/325/2007 is gratefully acknowledged.

\section{REFERENCES}

Abidemi, T. A., O. J. Adebayo, O. Idowu and M. O. Agbotoba. 2009. Nutrient content and anti-nutritional factors in shea butter (Butryospermum parkii) leaves. Afr. J. Biotechnol. 8: $5885-5890$

Association of Official Analytical Chemists. 1995. Official methods of analysis, 16th edition. Arlington, USA. pp. 4.1-4.17.

Asiegbu, F. O., A. Paterson, I. M. Morrison and J. E. Smith. 1995. Effect of cell wall phenolics and fungal metabolites on methane and acetate production under in vitro conditions. J. Gen. Appl. Microbiol. 41:475-485.

Barnett, A. J. G. and R. L. Reid. 1957. Studies on the production of volatile fatty acids from grass in artificial rumen. 1. Volatile fatty acids production from fresh grasses. J. Agric. Sci. (Cambridge). 48:315-321.

Bhatta, R., Y. Uyeno, K. Tajima, A. Takenaka, Y. Yabumoto, I. Nonaka, O. Enishi and M. Kurihara. 2009. Difference in the nature of tannins on in vitro ruminal methane and volatile fatty acid production, and methanogenic archaea and protozoal populations. J. Dairy Sci. 92:5512-5522.

Bhatta, R., U. Krishnamoorthy and F. Mohammed. 2001. Effect of tamarind (Tamarindus indica) seed husk tannins on in vitro rumen fermentation. Anim. Feed Sci. Technol. 90:143-152.

Bhatta, R., A. K. Shinde, S.Vaithiyanathan, S. K. Sankhyan and D. L. Verma. 2002. Effect of Polyethylene glycol-6000 on nutrient intake, digestion and growth of kids browsing 
Prosopis cineraria. Anim. Feed Sci. Technol. 101:45-54.

Bhatta, R., S. Vaithiyanathan, A. K. Shinde and R. C. Jakhmola. 2005. Effect of feeding complete feed block containing Prosopis cineraria leaves and polyethylene glycol (PEG)-6000 on nutrient intake, its utilization, rumen fermentation pattern and rumen enzyme profile in kids. J. Sci. Food Agric. 85:17881794.

Conway, E. J. 1957. Micro-diffusion Analysis and Volumetric Error. 4th edn. pp. 277-278. Crossby and Lockwood and Sons Ltd. London.

Dei, H. K., S. P. Rose and A. M. Mackenzi. 2007. Sheanut (Vitellaria paradoxa) meal as a feed ingredient for poultry. World's Poult. Sci. J. 63:611-624.

Dohme, F., A. Machmüller, B. L. Estermann, P. Pfister, A. Wasserfallen and M. Kreuzer. 1999. The role of the rumen ciliate protozoa for methane suppression caused by coconut oil. Lett. Appl. Microbiol. 29:187-192.

Field, J. A. and G. Lettinga. 1987. The methanogenic toxicity and anaerobic degradability of hydrolysable tannin. Water Res. 2: 367-374.

Hess, H. D., M. Kreuzer, T. E. Diaz, C. E. Lascano, J. E. Carulla and C. R. Soliva. 2003. Saponin rich tropical fruits affect fermentation and methanogenesis in faunated and defaunated fluid. Anim. Feed Sci. Technol. 109:79-94

Hristov, A. N., M. Ivan, L. Neill and T. A. McAllister. 2003. Evaluation of several potential bioactive agents for reducing protozoal activity in vitro. Anim. Feed Sci. Technol. 105:163184.

Hungate, R. E. 1966. The rumen and its microbes. pp. 26-36. Academic Press, London.

INRA. 2004. Tables of composition and nutritional value of feed materials. 2nd ed. (Ed. D. Sauvant, J. M. Perez and G. Tran) p. 186. Wageningen Academic Publishers, Netherlands.

Jayanegara, A., F. Leiber and M. Kreuzer. 2012. Meta-analysis of the relationship between dietary tannin level and methane formation in ruminants from in vivo and in vitro experiments. $\mathrm{J}$. Anim. Physiol. Anim. Nut. DOI: 10.1111/j.1439-0396.2011. 01172.x

Jouany, J. P. 1994. Manipulation of microbial activity in the rumen. Arch. Anim. Nutr. 46:133-153.

Jouany, J. P. and B. Lassalas. 1997. Study of the adaptation of the rumen ecosystem to the antimethanoginic effect of monensin measured in vivo. Reprod. Nutr. Dev. (Suppl.) S69-S70.

Kamra, D. N., R. K. Sawal, N. N. Pathank, N. Kewalramani and N. Aggarwal. 1991. Diurnal variation in ciliate protozoa in the rumen of black buck (Antelope cervicapra) fed green forage. Lett. Appl. Microbiol. 13:165-167.

Krishnamoorthy, U., H. Soller, H. Steingass and K. H. Menke. 1995. Energy and protein evaluation of tropical feedstuffs for whole tract and ruminal digestion by chemical analyses and rumen inoculum studies in vitro. Anim. Feed Sci. Technol. 52 177-188.
Kumar, K. M., K. Sudhakar, D. Nagalakshmi, M. Mahender, B. R. Gupta and V. S. T. Rao. 2010. Performance of lactating Murrah buffaloes on sheanut cake (Vitellaria paradoxa) based complete diets. Ind. J. Anim. Nutr. 27:389-395.

Leinmüller, E., H. Steingass and K. H. Menke. 1991. Tannins in feeds for ruminants. II Effects on rumen metabolism in vitro. Übersichten zur Tierernährung, 19:45-70.

Leinmuller, E. and K. H. Menke. 1990. Tannine in Futtermittenln fur Wiederkauer. 1. Chemische Eigenschaften und Reaktionen mit Makromolekulen. Ubers. Tierernahr. 18:91-114.

Lipp, M. and E. Anklam. 1998. Review of cocoa butter and alternative fats for use in chocolate-Part A. Composition data. Food Chem. 62:73-97.

Machmüller, A., C. R. Soliva and M. Kreuzer. 2003. Methane suppressing effect of myristic acid in sheep as affected by dietary calcium and forage proportion. Br. J. Nutr. 90:529-540.

Makkar, H. P. S. 2003. Quantification of tannins in tree and shrub foliage - A Laboratory Manual. Joint FAO/IAEA, Division of Nuclear Techniques in Food and Agriculture, Kluwer Academic Publishers, Dordrecht, The Netherlands.

McSweeny, C. S., B. Palmer, D. M. McNeill and D. O. Krause. 2001. Microbial interaction with tannins: nutritional consequences for ruminants. Anim. Feed Sci. Technol. 91:8393.

Menke, K. H., L. Raab, A. Salewski, H. Steingass, D. Fritz and W. Schneider. 1979. The estimation of digestibility and metabolizable energy content of ruminant feeding stuffs from the gas production when they are incubated with rumen inoculum in vitro. J. Agric. Sci. (Cambridge). 93:217-222.

SAS Institute. 2004. SAS/STAT user's guide, release 9.1.3. SAS Institute Inc., Cary, NC, USA.

Sliwinski, B. J., R. S. Carla, A. Machmuller and M. Kreuzer. 2002. Efficacy of plant extracts rich in secondary constituents to modify rumen fermentation. Anim. Feed Sci. Technol. 101:101-114

Terrill, T. H., G. B. Douglas, A. G. Foote, R. W. Purchas, G. F. Wilson and T. N. Barry. 1992. Effect of condensed tannin upon body growth, wool growth and rumen metabolism in sheep grazing sulla (Hedysarum coronarium) and perennial pasture. J. Agric. Sci. (Cambridge). 119:265-273.

Van Soest, P. J., J. B. Robertson and B. A. Lewis. 1991. Methods for dietary fibre, neutral detergent fibre and non-starch polysaccharides in relation to animal nutrition. J. Dairy Sci. 74:3583-3597.

Vogels, G. D., W. F. Hoppe and C. K. Stumm. 1980. Association of methanogenic bacteria with rumen ciliates. Appl. Environ. Microbiol. 39:123-128.

Wang, C. J., S. P. Wang and H. Zhou. 2009. Influences of flavomycin, ropadiar, and saponins on nutrient digestibility, rumen fermentation, and methane emission from sheep. Anim. Feed Sci. Technol. 148:157-166. 